\title{
In support of water-resource planning - highlighting key management issues using DRIFT: A case study
}

\author{
C Brown ${ }^{1 *}$, C Pemberton 1 , A Birkhead ${ }^{2}$, A Bok ${ }^{3}$, C Boucher 4 , E Dollar ${ }^{5}$, W Harding 6 , \\ W Kamish', J King', B Paxton ${ }^{8}$ and S Ractliffe ${ }^{8}$ \\ ${ }^{1}$ Southern Waters Ecological Research and Consulting, Zoology Department, University of Cape Town, PO Box 12414, \\ Cape Town 8010, South Africa \\ ${ }^{2}$ Streamflow Solutions, PO Box 889, Gonubie 5256, South Africa \\ ${ }^{3}$ Anton Bok Aquatic Consultants, 5 Young Lane, Mill Park, Port Elizabeth 6001, South Africa \\ ${ }^{4}$ Botany Department, University of Stellenbosch, Private Bag X1, Matieland 7602, South Africa \\ ${ }^{5}$ ESJ Dollar Consulting, 40 Susan Crescent, Langeberg Heights 7570, South Africa \\ ${ }^{6}$ DH Environmental Consulting, PO Box 5429, Helderberg 7135, South Africa \\ ${ }^{7}$ Ninham Shand, PO Box 1347, Cape Town 8000, South Africa \\ ${ }^{8}$ Freshwater Research Unit, Zoology Department, University of Cape Town, Private Bag, Rondebosch 7700, South Africa
}

\begin{abstract}
The DRIFT (downstream response to imposed flow transformation) methodology was applied as part of a comprehensive Reserve determination study on the Olifants-Doring River, Western Cape, South Africa. DRIFT was used to provide flow scenarios, and descriptive summaries of their consequences in terms of the condition of the river ecosystem, for examination and comparison by decision makers, managers and users. The methods used and results obtained in that study are presented and discussed in the light of the study constraints of time and money, the lack of historical data, and the urgent need to provide clear, easily-understandable information on the consequences for the river ecosystem of various tradeoffs characteristic of water resource developments. The results indicated that abstracting during high flows in winter and river restoration work can have positive ecological and agricultural returns.
\end{abstract}

Keywords: environmental water requirements; Ecological Reserve; DRIFT; scenarios; river condition; tradeoffs

\section{Introduction}

The South African National Water Act (NWA; No. 36 of 1998) is founded on the principle that National Government has overall responsibility for, and authority over, water-resource management for the benefit of the public without seriously affecting the functioning of the natural environment, i.e., sustainable utilisation of the resource. In order to achieve this objective, Chapter 3 of the NWA provides for the protection of water resources through the Ecological Reserve (NWA, 1998).

The Department of Water Affairs and Forestry (DWAF) Directorate: Resource Directed Measures (D:RDM) is tasked with the responsibility of ensuring that the Reserve requirements, which have priority over other uses in terms of the NWA, are determined before licence applications are processed, particularly in stressed catchments. The Reserve refers to both the Ecological Reserve and the Basic Human Needs Reserve. The Olifants/Doring River catchment is deemed to be one such system and a comprehensive determination of the Reserve was therefore commissioned in 2003, and Southern Waters Ecological Research and Consulting were appointed to lead the technical aspects of the study.

The study as a whole encompassed separate flow determinations for the river, the estuary and the groundwater systems (Brown et al., 2003). This paper concentrates on the river system and outlines the approach used and results obtained, using

* To whom all correspondence should be addressed.

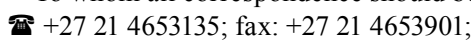

e-mail: cbrown@southernwaters.co.za

Received 26 July 2005; accepted in revised form 19 December 2005. one of the study sites (Site 1) as an example. The results of the study are intended to support water-allocation planning, in accordance with the requirements of the NWA and the National Water Resource Strategy (DWAF, 2002).

The process for determining the Ecological Reserve for river ecosystems is stipulated by DWAF (DWAF, 1999) and comprises eight steps:

Step 1. Initiate the study

Step 2. Define the resource units

Step 3. Ecoclassification

Step 4. Quantify ecological water requirement scenarios

Step 5. Ecological consequences of flow scenarios

Step 6. Decision-making process

Step 7. Ecological RQOs

Step 8. Operationalising the Reserve.

Step 1 is essentially an internal DWAF process, where the applicability and limitations of different levels of Reserve determination are evaluated and a level appropriate to the study river decided on. The level chosen dictates, inter alia, the duration of the study, the disciplines represented, the intensity and frequency of data collection and the method used. In the case of the Olifants-Doring study, a comprehensive level of determination was decided on, which provided for a two-year study period and, for the river component, a team of specialists representing six disciplines, namely: hydrology, hydraulics, geomorphology, water quality, botany, macroinvertebrate ecology and fish ecology.

Step 2 involves the division of the study catchment into representative ecosystems, e.g., rivers, wetlands, estuaries or groundwater, and representative reaches within each of the ecosystems identified. For the Olifants-Doring study, this process 


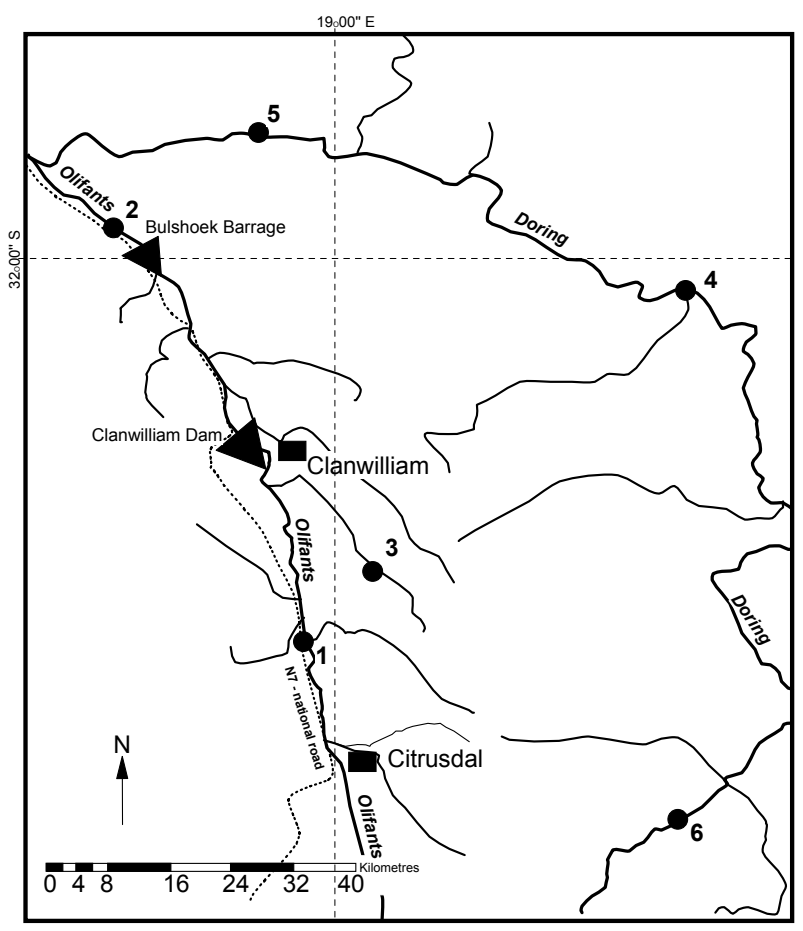

Figure 1

Map of the study area showing the location of the six study sites

is discussed in Brown et al. (2004), and resulted in the selection of six study sites spread throughout the catchment.

Step 3 is an evaluation of the ecological condition of the selected study reaches/sites relative to their natural or undisturbed condition. This again is guided by set procedures provided by DWAF, which are explained in detail elsewhere (e.g. Kleynhans, 1996; Kleynhans et al., 2005).

Step 4 is the actual environmental flow assessment, and is the focus of this paper. It culminated in flow assessments for the six representative sites in the Olifants-Doring catchment, each of which allowed for the evaluation of several flow-related scenarios.

Step 5 involves using the results achieved in Step 4 to evaluate the ecological consequences of one or more future flow regimes, which represent 'realistic' operational scenarios for the system. Step 5 leads into Steps 6 to 8 , in which, for each site, one of the scenarios is selected as the Ecological Reserve for implementation, and thereafter is expanded to include monitoring and evaluation criteria, the so-called Resource Quality Objectives (DWAF, 1999), and rules that dictate, inter alia, the operation of dams, the issuing of licences and the extrapolation of results to other parts of the catchment.

\section{Study area and study sites}

The Olifants/Doring River catchment is situated in the southwest of South Africa, in a winter rainfall region. The Olifants
River itself rises on the Agter Witzenberg plateau, which is an agricultural area situated between the Skurweberge, the Groot Winterhoekberge and the Witzenberg at an altitude of approximately $800 \mathrm{~m}$ (Dallas, 1997; Fig. 1). It rises as a network of small mountain streams and wetland areas. Whilst most of these smaller streams do not flow during summer, the main river is naturally perennial. From the plateau, the river flows northwards for $12 \mathrm{~km}$ before entering a narrow gorge for $30 \mathrm{~km}$. It emerges into a wide valley at Keerom after which it flows northwards for a further $100 \mathrm{~km}$ between the Olifantsrivierberge, Swartberg and the Cederberg Mountain ranges. Numerous small tributaries join the Olifants River in its upper reaches and two major tributaries, the Doring and the Hol Rivers, join the river near the towns of Klawer and Vredendal, respectively. The river reaches the sea at Papendorp (Dallas, 1997).

The mean annual precipitation over much of the catchment is less than $200 \mathrm{~mm}$, with the result that, except in the wetter south-west, the climate is not suitable for dryland farming on a large scale. Approximately 113000 people live alongside the Olifants River or in its immediate catchment (excluding the Doring River), and the irrigated citrus, deciduous fruits, grapes and potatoes that are grown in the Olifants Valley provide the mainstay of the catchment's economy.

In an ecological sense, rivers should be viewed as continuous longitudinal systems. They possess continuous gradients of physical and chemical conditions that are progressively and continuously modified downstream from the headwaters to the sea (Vannote et al., 1980) and changes taking place in the upstream reaches will influence downstream processes. Different sections of a river can however have different natural flow patterns, and can react differently to flow-related and other external stresses according to their individual sensitivities. As a result they often require individual specifications of their environmental flows. Furthermore, in order to facilitate the best management of a river, it needs to be broken down into discrete, manageable units. Biophysical and social considerations and the practicalities of a certain number of units need to be taken into account when identifying these units. Louw and Birkhead (1999) suggest that, for a comprehensive Reserve determination in South Africa, four EWR sites, selected correctly, will normally cater for a river length of 100 to $200 \mathrm{~km}$. However, the number of EWR sites influences the cost and time required for the study and, in this study (as is often the case), site number was dictated by financial considerations. The total number of sites for the study was limited to six (Fig. 1), with two of these being on the Olifants River, two on the Doring River (its major tributary) and the remaining two small tributaries, viz. the Rondegat River, which flows into the Olifants River, and the Groot River, which flows into the Doring River. This equated to approximately two sites per 200 $\mathrm{km}$ of river. The locations of the six sites are indicated in Fig. 1. The reasons for their selection and the process adopted are covered in detail in Brown et al. (2004). Site 1 (Table 1), the focus of this paper, was taken as being representative of the Olifants River from Citrusdal to the Bulshoek Dam.

\begin{tabular}{|l|l|}
\hline \multicolumn{2}{|c|}{$\begin{array}{l}\text { TABLE 1 } \\
\text { Details for Site 1 on the Olifants River }\end{array}$} \\
\hline Coordinates : & S 32 26.764; E 18 57.601. \\
\hline Locality : & Adjacent to the N7 downstream of Citrusdal and upstream of the confluence with the Hex River. \\
\hline Hydrology: & There is no DWAF gauging weir but flows in the river can be estimated from inflows to Clanwilliam Dam. \\
\hline Access: & From a lay-by on the N7. \\
\hline $\begin{array}{l}\text { Hydraulic cross- } \\
\text { sections: }\end{array}$ & $\begin{array}{l}\text { Two cross-sections were selected to characterise the hydraulic relationships at EWR Site 1 (Fig. 2). These } \\
\text { were: CS la: Across a riffle; CS 1b: Across a pool section. }\end{array}$ \\
\hline
\end{tabular}




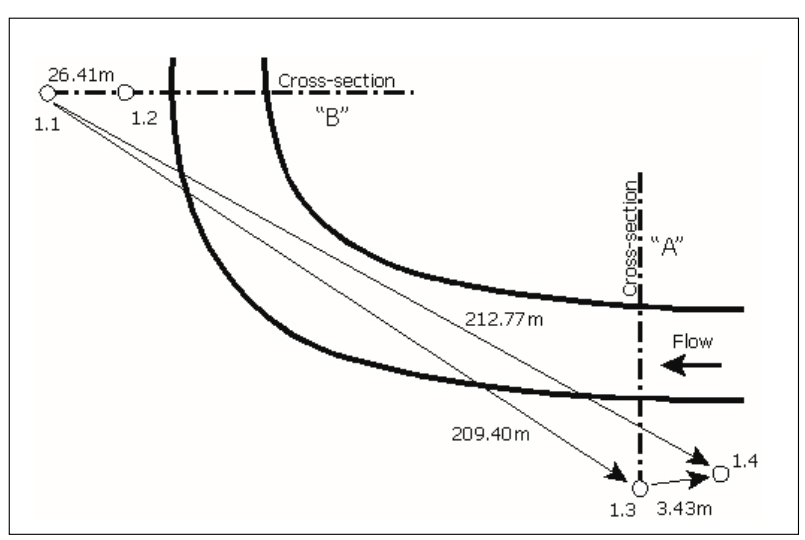

Figure 2

Plan layouts for EWR Site 1

Site 1 was located on a bend in the river, which was a lessthan-ideal situation from the perspective of hydraulic modelling. The site, however, offered a wider range of habitat types and was in considerably better ecological condition than the remaining sections in this reach. Thus, as is typically the case, the consideration of a wide array of requirements for a site, including those related to physical safety of the researchers, resulted in the selection of a site that was less than ideal for most disciplines but better than anything on offer elsewhere. The plan layout of Site 1 is provided in Fig. 2. The top portion of the site near Transect 1a was composed of shallow riffle and run habitat, overlying small- to medium-sized cobbles. This cobble-bed section is uncharacteristic of the reach, but was included because such sections are typically more sensitive to flow changes than runs or pools (Gordon, 1992). The banks in this section were relatively steep, and appeared to be artificial. They were composed of large cobbles and boulders, interspersed with patches of palmiet (Prionium serratum), with light infestation of Eucalyptus spp. at the tops of the banks. Cross- sections were positioned across the riffle and pool, upstream and downstream of river bend, respectively. The lower portion of the site (Transect $1 \mathrm{~b}$ ) was a sand bed river and was bound by sandbanks and dense stands of palmiet on the right bank, and a steep artificial boulder bank (supporting the N7 National Road between Cape Town and Windhoek) on the left. This lower section of the site consisted of deep sandy runs and pools, which are characteristic of this reach of the Olifants River. The site was approximately $250 \mathrm{~m}$ in length.

\section{Methods}

\section{Ecoclassification}

Present ecological status (PES) was determined using the ecostatus model (Kleynhans et al., 2005) and a water quality model (salts only) provided by DWAF: RQS (Jooste, 2004). Results from both models were altered in the event that they did not agree with the specialists' assessment of PES, and motivation for these changes provided, where applicable.

\section{Flow assessment}

The DRIFT (Downstream Response to Imposed Flow Transformation) Method (Brown et al., 2005), an interactive, holistic method for advising on environmental flows for rivers targeted for water-management activities, was used to assess the flow requirements for the selected sites on the Olifants-Doring River. In its totality, DRIFT consists of four modules (biophysical, social use, scenario development and compensation economics (King et al., 2003) but only Modules 1 (biophysical) and 3 (scenario development) were used in this study.

The key feature of DRIFT is that it provides a structure to specialist deliberations on the consequences of flow changes. Data collection and subsequent deliberations concentrate on river sites, each of which is selected based on it being representative of a river reach as far as possible.

TABLE 2

Present-day flow categories for Site 1 and change levels considered by the specialists at the workshop

\begin{tabular}{|c|c|c|c|c|c|c|}
\hline Flow category & $\begin{array}{l}\text { Magnitude } \\
\left(\mathrm{m}^{3} \cdot \mathbf{s}^{-1}\right)\end{array}$ & $\begin{array}{l}\text { Timing/fre- } \\
\text { quency } \\
\text { - present } \\
\text { day }\end{array}$ & Change 1 & Change 2 & Change 3 & Change 4 \\
\hline \multicolumn{7}{|c|}{ LOW FLOWS } \\
\hline $\begin{array}{l}\text { Dry season low } \\
\text { flows }\end{array}$ & $\begin{array}{l}0.2-4.6 \\
\text { (Fig. 2) }\end{array}$ & $\begin{array}{l}\text { November } \\
\text { to April }\end{array}$ & $\begin{array}{l}\text { Reduction: Capped } \\
\text { at } 20^{\text {th }} \text { percentile }\end{array}$ & $\begin{array}{l}\text { Increase: Mini- } \\
\text { mum dry sea- } \\
\text { son lowflow of } \\
0.01 \mathrm{~m}^{3} \mathrm{~s}^{-1}\end{array}$ & $\begin{array}{l}\text { Increase: Rein- } \\
\text { state to } 50^{\text {th }} \\
\text { percent-ile on } \\
\text { the Naturalised } \\
\text { FDC }\end{array}$ & None \\
\hline $\begin{array}{l}\text { Wet season low } \\
\text { flows }\end{array}$ & $\begin{array}{l}16.5-69.3 \\
\text { (Fig. 2) }\end{array}$ & $\begin{array}{l}\text { May to } \\
\text { October }\end{array}$ & $\begin{array}{l}\text { Reduction: Capped } \\
\text { at the } 10^{\text {th }} \text { percentile } \\
\text { on the Present Day } \\
\text { FDC }\end{array}$ & $\begin{array}{l}\text { Reduction: } \\
\text { Capped at the } \\
40^{\text {th }} \text { percentile } \\
\text { on PD FDC }\end{array}$ & $\begin{array}{l}\text { Reduction: } \\
\text { Capped at the } \\
70^{\text {th }} \text { percentile } \\
\text { on PD FDC }\end{array}$ & $\begin{array}{l}\text { Reduction: } \\
\text { Capped at the } \\
90^{\text {th }} \text { percentile } \\
\text { on PD FDC }\end{array}$ \\
\hline \multicolumn{7}{|c|}{ FLOODS } \\
\hline Flood Class 1 & $7.00-14.20$ & 13 per annum & Decrease (6) & Decrease (3) & Decrease (1) & Decrease (0) \\
\hline Flood Class 2 & $14.21-28.40$ & 1 per annum & Decrease $(0)$ & & & \\
\hline Flood Class 3 & $28.41-56.82$ & 1 per annum & Decrease $(0)$ & & & \\
\hline Flood Class 4 & $56.83-113.65$ & 1 per annum & Decrease $(0)$ & & & \\
\hline Flood Class 5 & 126.28 & $1: 2$ & Absent & & & \\
\hline Flood Class 6 & 166.02 & $1: 5$ & Absent & & & \\
\hline Flood Class 7 & 194.77 & $1: 10$ & Absent & & & \\
\hline Flood Class 8 & 194.77 & $1: 20$ & Absent & & & \\
\hline
\end{tabular}



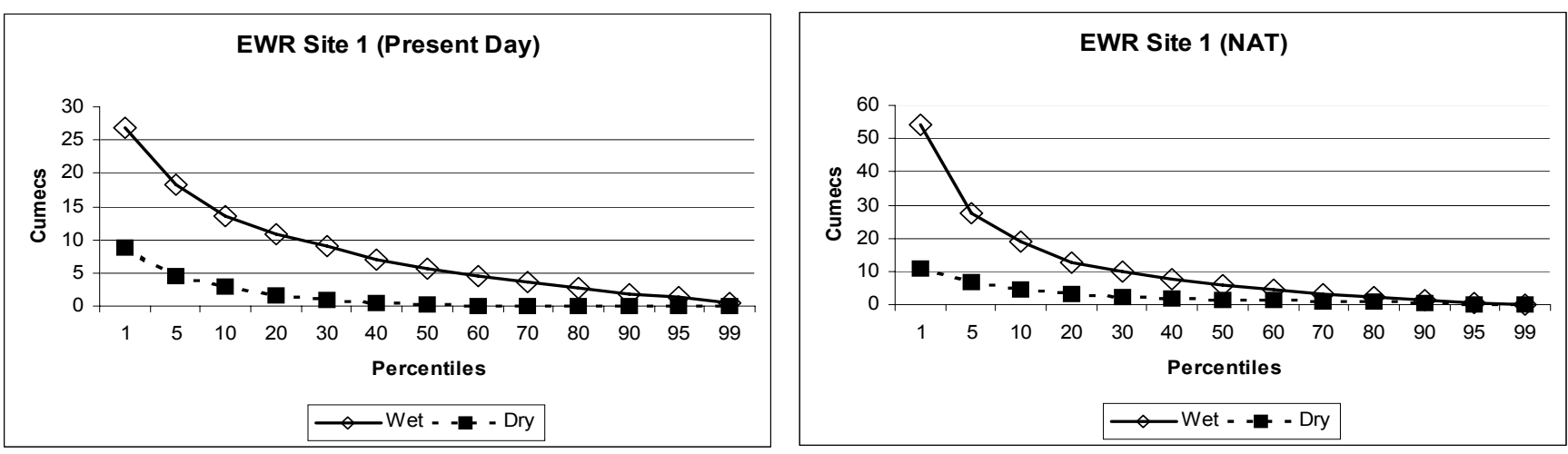

Figure 3

Present day (left) and naturalised (right) low-flow flow duration curves for the wet and dry seasons at Site 1. Please note the $y$-axes differ between the two charts.

The present-day long-term daily flow data for each site were separated into ten flow classes (Table 2; Fig. 3), and specialists predict the consequences of up to four levels of change from present conditions in each flow class (Table 2) for different biophysical components of the river ecosystem (Table 3).
The consequences of each considered flow change for each of the study sites were deliberated and decided on at a five-day workshop, attended by the full river team, held in November 2004. The workshop situation enabled specialists to discuss possible consequences with other specialists and ensure that they took into

\begin{tabular}{|c|c|c|}
\hline \multicolumn{3}{|c|}{$\begin{array}{c}\text { TABLE } 3 \\
\text { The hierarchical arrangement of ecosystems components, sub-components and elements represented on } \\
\text { the Olifants-Doring study (river only) }\end{array}$} \\
\hline Component & Sub-component & Element \\
\hline Hydrology & \multicolumn{2}{|l|}{ As per Table 2} \\
\hline Hydraulics & \multicolumn{2}{|l|}{ Not applicable } \\
\hline Water quality & $\begin{array}{l}\text { Temperature, dissolved oxy- } \\
\text { gen, salinity }\end{array}$ & None listed \\
\hline \multirow[t]{7}{*}{ Geomorphology } & Depth & Pool, riffle \\
\hline & Width & Pool, riffle \\
\hline & Bed slope & Pool, riffle \\
\hline & Potential bed transport & Pool, riffle \\
\hline & Geodiversity of bed & Pool, riffle \\
\hline & Quantity of fines on the bed & Pool, riffle \\
\hline & Overbank sedimentation & None listed \\
\hline \multirow[t]{7}{*}{ Botany } & Floating aquatics & Lemna/Azolla \\
\hline & Rooted aquatic vegetation & Nymphaea nouchali, Typha capensis, Phragmites australis \\
\hline & Lower wetbank & Juncus lomatophyllus, Isolepis prolifer, Prionium, Isolepis digitata \\
\hline & Upper wetbank & $\begin{array}{l}\text { Panicum repens, Sesbania punicea, Salix mucronata, Prionium } \\
\text { serratum }\end{array}$ \\
\hline & Lower dynamic zone & Woody invasives \\
\hline & Tree shrub zone & Woody invasives, indigenous woody vegetation \\
\hline & Upper dynamic zone & Woody invasives, Rhus angustifolia \\
\hline \multirow[t]{7}{*}{$\begin{array}{l}\text { Macroinvertebrate } \\
\text { ecology }\end{array}$} & Detritivorous mayflies & $\begin{array}{l}\text { Pseudopannota sp., Pseudocloeon vinosum, Caenidae, Ecnomidae, } \\
\text { Demoulinia (Baetidae) }\end{array}$ \\
\hline & Mobile grazers & $\begin{array}{l}\text { Emoreptus capensis, Baetis spp. (Baetidae), Afronurus barnardi } \\
\text { (Heptageniidae), Teleganodidae }\end{array}$ \\
\hline & Less-mobile grazers & Leptoceridae, Elmidae, Blephariceridae, Crambiidae, Dryopidae \\
\hline & Collectors & Hydropsychiidae, Philopotamidae \\
\hline & Flow-sensitive predators & Corydalidae, Athericidae \\
\hline & Hardy predators & Libellulidae, Cordulidae, Gomphidae, Coenagrionidae, Aeschnidae \\
\hline & Shredders & Notonemoridae, Sericostomatidae \\
\hline \multirow[t]{4}{*}{ Fish ecology } & Invasive centrarchid & Small-mouthed bass \\
\hline & Large endemic cyprinids & Clanwilliam Yellowfish \\
\hline & Minnows & Clanwilliam Redfin, Fiery Redfin \\
\hline & Rock catfish & Clanwilliam Rock Catfish, Barnard's Rock Catfish \\
\hline
\end{tabular}




\begin{tabular}{|c|c|c|c|}
\hline \multicolumn{4}{|c|}{$\begin{array}{c}\text { TABLE } 4 \\
\begin{array}{c}\text { Summary of the individual PES assessments comprising } \\
\text { the present ecostatus for Site } 1\end{array}\end{array}$} \\
\hline Driver components & Component PES & Driver PES & PES \\
\hline Hydrology & $\mathrm{D}$ & \multirow[t]{3}{*}{$\mathrm{D}$} & \multirow[t]{7}{*}{$\mathrm{D}$} \\
\hline Geomorphology & $\mathrm{E}$ & & \\
\hline Water quality & $\mathrm{B}$ & & \\
\hline Response components & Component PES & Response PES & \\
\hline Fish & $\mathrm{D}$ & \multirow[t]{3}{*}{$\mathrm{D}$} & \\
\hline Macroinvertebrates & $\mathrm{C}$ & & \\
\hline Vegetation & $\mathrm{C}$ & & \\
\hline
\end{tabular}

account as many of the interactions as possible that were likely to affect their component. The full matrix of consequences, completed by the specialists, for the range of possible changes in the ten flow categories (viz. two dry season categories and eight flood classes; Table 2), was then entered into the DRIFT Database, together with information on the data sources used. The DRIFT Database is a series of MS Excel spreadsheets that stores the matrix of flow-response couplets, predicted by the specialists, for a range of possible flow changes; uses this matrix to compute the ecological consequences of different volumes and distributions of water being made available for river maintenance (flow scenarios); summarises the ecological consequences of flow scenarios relative to the present ecological state of the river; and allows predictions to be updated should new information become available.

Each consequence was accompanied by an integrity rating, which indicates:

- If the subcomponent (Table 3) is expected to increase or decrease in abundance, magnitude or size

- The severity of that increase/decrease, on a scale of 0 (no measurable change) to 5 (very large change

- Whether the predicted change represents a move towards (+ve) or away from (-ve) natural.

The DRIFT database was then checked for errors and thereafter used to create summary plots of the predicted results using DRIFT SOLVER and DRIFT CATEGORY (Brown and Joubert, 2003). DRIFT SOLVER contains an integer linear programming multicriteria analysis (MCA) method, which generates optimally distributed flow scenarios for different total annual volumes of water. DRIFT CATEGORY facilitates evaluation of these in terms of river condition.

\section{Hydrology}

The naturalized MAR (nMAR) at Site 1 was estimated at 331.5 MCM and present day MAR (pdMAR) at 274.7 (i.e., $83 \%$ of nMAR). However, at Site 1, the dry season low flows were considerably reduced relative to their natural levels (Fig. 3). There was thus some merit in predicting the consequences of increasing these, and the selected change levels encompassed both decreased and increased, i.e., restoration, flow. Each biophysical specialist (Table 3) chose her/his own component-specific methods to derive the kinds of flow-related links required to provide answers to the questions posed by DRIFT (Birkhead et al., 2005).

\section{Biophysical components}

Specialist data-collection and evaluation for each of the biophysical components took place over 12 months; encompassing one full hydrological year. Each biophysical specialist chose her/his own component-specific methods for the collection, analysis and interpretation of data that assist in understanding the links with the flow classes in Table 2 (e.g., Arthington et al., 2003).

When recording the consequences of each flow change, the specialists considered a number of subcomponents and/or elements that may be relevant to their ecosystem component (Table 3). Subcomponents may comprise channel (physical) features, chemical features, communities or individual species, and are chosen because of their known susceptibility to flow changes, their role as key species or features, or their relevance to subsistence users (King et al., 2003).

\section{Results}

\section{Ecoclassification}

The present ecostatus for Site 1 was Category D (Table 4), with the major factors contributing to deviation from the natural condition identified as: manual manipulation of the river channel (non-flow related); cultivation of the floodplain (non-flow related); reduced summer flows and long no-flow periods over the summer (flow related), and invasion by alien vegetation (mainly non-flow related). An explanation of the PES categories is provided in Table 5 .

\section{Biophysical consequences}

For each site, approximately 1000 consequences of flow change were recorded for the five biophysical components in the study (geomorphology, water quality, vegetation, macroinvertebrates and fish). These are provided in Brown and Pemberton (2005). An example of consequences returned for one sub-component of the macroinvertebrates for successive reductions, through four change levels, in wet season low flows at Site 1 is given in Table 6.

In Table 6, 'severity rating' denotes the severity of the predicted change (if any) in terms of a range between 0 (no change) and 5 (highly significant change); 'direction of change' denotes an increase (I) or decrease (D) in the abundance of an element; 'towards or away from natural' is an indication of whether the change represents a move towards or away from the natural condition of the river; and, 'data source' denotes the quality of the supporting data, viz. high (H), medium (M) or low (L), according to the following criteria (King et al., 2003):

$\mathrm{H}$ Supported by studies on the same species/process/river that have been published in peer-reviewed papers, books or reports 


\begin{tabular}{|l|l|}
\hline \multicolumn{2}{|l|}{ The South African river categories (DWAF, 1999) } \\
\hline Category & Description \\
\hline A & Unmodified, natural. \\
\hline B & $\begin{array}{l}\text { Largely natural with few modifications. A small change in natural habitats and biota may have taken place but the } \\
\text { ecosystem functions are essentially unchanged. }\end{array}$ \\
\hline C & $\begin{array}{l}\text { Moderately modified. A loss and change of natural habitat and biota have occurred but the basic ecosystem func- } \\
\text { tions are still predominantly unchanged. }\end{array}$ \\
\hline D & Largely modified. A large loss of natural habitat, biota and basic ecosystem functions has occurred. \\
\hline E & The loss of natural habitat, biota and basic ecosystem functions is extensive. \\
\hline F & $\begin{array}{l}\text { Modifications have reached a critical level and the lotic system has been modified completely with an almost com- } \\
\text { plete loss of natural habitat and biota. In the worst instances the basic ecosystem functions have been destroyed } \\
\text { and the changes are irreversible. }\end{array}$ \\
\hline
\end{tabular}

\begin{tabular}{|c|c|c|c|c|c|c|c|c|c|}
\hline \multicolumn{10}{|c|}{$\begin{array}{c}\text { TABLE } 6 \\
\begin{array}{c}\text { Example of consequences returned for one sub-component (detritivorous mayflies) } \\
\text { of the macroinvertebrates for changes in wet season low flows }\end{array}\end{array}$} \\
\hline \multirow[t]{3}{*}{ Wet season lowflows } & \multicolumn{9}{|c|}{ Macroinvertebrates } \\
\hline & \multirow{2}{*}{$\begin{array}{l}\text { Sub-component } \\
\text { Element } \\
\end{array}$} & \multicolumn{8}{|c|}{ Detritivorous Mayflies } \\
\hline & & \multicolumn{2}{|c|}{ Riffle/Run } & \multicolumn{2}{|c|}{ Instream } & \multicolumn{2}{|c|}{$\begin{array}{l}\text { Marginal } \\
\text { vegetation }\end{array}$} & \multicolumn{2}{|c|}{$\begin{array}{l}\text { Stones out } \\
\text { of current/ } \\
\text { sand }\end{array}$} \\
\hline \multirow[t]{5}{*}{ Change level 1} & Severity rating & 0 & 1 & 0 & 1 & 0 & 1 & 0 & 1 \\
\hline & Direction of change & \multicolumn{2}{|c|}{ Increase } & \multicolumn{2}{|c|}{ Increase } & \multicolumn{2}{|c|}{ Increase } & \multicolumn{2}{|c|}{ Increase } \\
\hline & Toward/away from natural & \multicolumn{2}{|c|}{ Away } & \multicolumn{2}{|c|}{ Away } & \multicolumn{2}{|c|}{ Away } & \multicolumn{2}{|c|}{ Away } \\
\hline & Data source & \multicolumn{2}{|c|}{$\mathrm{M}$} & \multicolumn{2}{|c|}{ M } & \multicolumn{2}{|c|}{ M } & \multicolumn{2}{|c|}{$\mathrm{M}$} \\
\hline & Integrity rating & 0 & -1 & 0 & -1 & 0 & -1 & 0 & -1 \\
\hline \multirow[t]{5}{*}{ Change level 2} & Severity rating & 0 & 2 & 0 & 2 & 0 & 1 & 0 & 2 \\
\hline & Direction of change & \multicolumn{2}{|c|}{ Increase } & \multicolumn{2}{|c|}{ Increase } & \multicolumn{2}{|c|}{ Increase } & \multicolumn{2}{|c|}{ Increase } \\
\hline & Toward/away from natural & \multicolumn{2}{|c|}{ Away } & \multicolumn{2}{|c|}{ Away } & \multicolumn{2}{|c|}{ Away } & \multicolumn{2}{|c|}{ Away } \\
\hline & Data source & \multicolumn{2}{|c|}{$\mathrm{M}$} & & & & & & \\
\hline & Integrity rating & 0 & -2 & 0 & -2 & 0 & -1 & 0 & -2 \\
\hline Change level 3 & Severity rating & 1 & 3 & 0 & 2 & 0 & 2 & 2 & 3 \\
\hline & Direction of change & & & & & & ase & & ase \\
\hline & Toward/away from natural & & & & & & & & \\
\hline & Data source & & & & & & & & \\
\hline & Integrity rating & -1 & -3 & 0 & -2 & 0 & -2 & -2 & -3 \\
\hline Change level 4 & Severity rating & 2 & 3 & 0 & 2 & 0 & 1 & 2 & 4 \\
\hline & Direction of change & & & & & & ase & & ase \\
\hline & Toward/away from natural & & & & & & & & \\
\hline & Data source & & & & & & & & \\
\hline & Integrity rating & -2 & -3 & 0 & -2 & 0 & -1 & -2 & -4 \\
\hline
\end{tabular}

M Supported by studies in peer-reviewed papers, books or reports on similar species/processes/rivers; unpublished data on the same species/processes/rivers or direct observations in the study river

$\mathrm{L}$ The recommendation is made on the basis of anecdotal information or professional judgement.

Finally 'severity rating' and 'towards/away' from natural combine to provide the integrity rating, where the move away or towards natural is illustrated by a positive $(+)$ or negative (-) before the severity rating.

An excerpt of the DRIFTSOLVER spreadsheet for Site 1 is provided in Table 7. Here the integrity ratings for each element have been combined through the sub-component level to the component level for up to four levels of flow change in wet season low flows, dry season low flows and Class 1 floods. The optimally distributed flow scenarios for different total annual volumes of water are created by off-setting the resultant DRIFT total score against the volume of water associated with each change level (see Brown and Joubert, 2003 for details).

It is interesting to note that changes in the low flows are not expected to affect the physical habitat (geomorphology), whereas changes in the small Class 1 floods are expected to have some impact on physical habitat, with a concomitant effect on the other (biological) components. Similarly, reduction in wet season low flows are not anticipated to have a noticeable affect on water quality until Change Levels 3 and 4, which represent a considerable reduction of water in the river channel (almost half that available at present; PD). Conversely, increasing the amount of water available in summer (dry season low flows Change Level 3) is expected to have a positive impact on the system, as is a change in the distribution of flows in the dry sea- 


\begin{tabular}{|c|c|c|c|c|c|c|c|c|c|}
\hline \multicolumn{10}{|c|}{$\begin{array}{c}\text { TABLE } 7 \\
\text { Excerpt of the DRIFTSOLVER spreadsheet for Site } 1\end{array}$} \\
\hline \multirow[b]{2}{*}{ 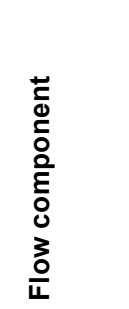 } & \multirow[b]{2}{*}{ 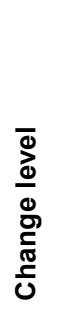 } & \multirow[b]{2}{*}{ 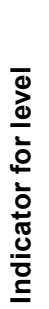 } & \multirow[b]{2}{*}{ 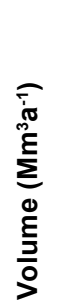 } & \multicolumn{5}{|c|}{ Ecosystem component } & \multirow[b]{2}{*}{ 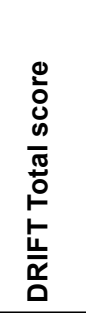 } \\
\hline & & & & 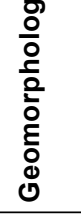 & 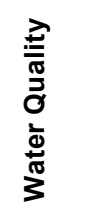 & 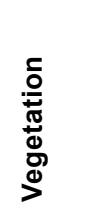 & 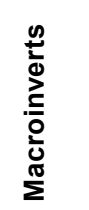 & $\frac{c}{\frac{n}{i n}}$ & \\
\hline \multirow{5}{*}{$\begin{array}{l}\text { Wet low } \\
\text { flows }\end{array}$} & PD & 0 & 94 & 0.00 & 0.00 & 0.00 & 0.00 & 0.00 & 0.00 \\
\hline & 1 & 0 & 87.3 & 0.00 & 0.00 & -0.21 & -0.48 & -0.29 & -0.20 \\
\hline & 2 & 0 & 72.5 & 0.00 & 0.00 & -0.54 & -1.14 & -0.14 & -0.36 \\
\hline & 3 & 0 & 52.2 & 0.00 & -0.10 & -1.04 & -2.24 & -0.79 & -0.83 \\
\hline & 4 & 1 & 30.8 & 0.00 & -0.30 & -1.39 & -2.72 & -1.50 & -1.18 \\
\hline \multirow{4}{*}{$\begin{array}{l}\text { Dry low } \\
\text { flows }\end{array}$} & PD & 0 & 18.4 & 0.00 & 0.00 & 0.00 & 0.00 & 0.00 & 0.00 \\
\hline & 1 & 0 & 14.3 & 0.00 & -0.90 & -0.45 & -0.51 & -0.88 & -0.55 \\
\hline & 2 & 0 & 18.4 & 0.00 & 0.20 & -0.29 & 0.17 & 0.13 & 0.04 \\
\hline & 3 & 1 & 25.2 & 0.00 & 1.20 & -0.05 & 1.02 & 1.63 & 0.76 \\
\hline \multirow{5}{*}{$\begin{array}{l}\text { Floods: } \\
\text { Class } 1\end{array}$} & $\mathrm{PD}$ & 0 & 42.9 & 0.00 & 0.00 & 0.00 & 0.00 & 0.00 & 0.00 \\
\hline & 1 & 1 & 19.8 & -0.43 & -0.50 & 0.00 & -1.49 & -0.88 & -0.66 \\
\hline & 2 & 0 & 9.9 & -0.43 & -0.60 & 0.00 & -1.63 & -1.13 & -0.76 \\
\hline & 3 & 0 & 3.3 & -0.43 & -0.90 & -0.40 & -1.91 & -2.38 & -1.20 \\
\hline & 4 & 0 & 0 & -0.43 & -0.90 & -0.40 & -1.98 & -2.63 & -1.27 \\
\hline
\end{tabular}

son, without altering the volume of water made available to the system over that period (dry season low flows Change Level 2).

\section{DRIFT category}

The DRIFT category output for Site 1 (Fig. 4) was generated by calculating the maximised DRIFT integrity scores for different annual volumes of water, distributed in the least damaging manner, i.e., distributed over the year in the way most beneficial to the river ecosystem within the limits of the flow categories and change levels assessed. Thus each of the data points in Fig. 5 represents the resultant river condition (relative to the present-day condition) (y-axis) achieved through a stipulated flow regime comprising a specific volume of water (x-axis). The present-day condition of the river is represented by DRIFT integrity score of zero (Table 6 and Fig. 4). Thus, negative changes integrity (below 0 ) will result in a decline in condition relative to the present-day situation and positive changes (above 0 ) in an improvement in overall condition, relative to present day. The present-day flow regime ( $83 \%$ nMAR) is indicated by the circle in Fig. 4, but it is clear that (according to the result obtained) the present day distribution of flows is deemed to be less than optimal and that an improvement in condition could be achieved using the same volume of water distributed in a more beneficial manner. In this case, that would translate to a reinstatement of some of the dry season low flows, with a concomitant increase in wet season abstractions.

The solid horizontal line in Fig. 4 depicts the position at which river condition is expected to change from one category to the next, i.e., it estimates the position of the threshold between categories (D and E). For example, the PES of Site 1 is D, and is represented by an integrity score of 0 in the figure. Overall decline in condition, i.e., negative overall integrity score, would lead to an E (i.e., below the solid black line) category river.

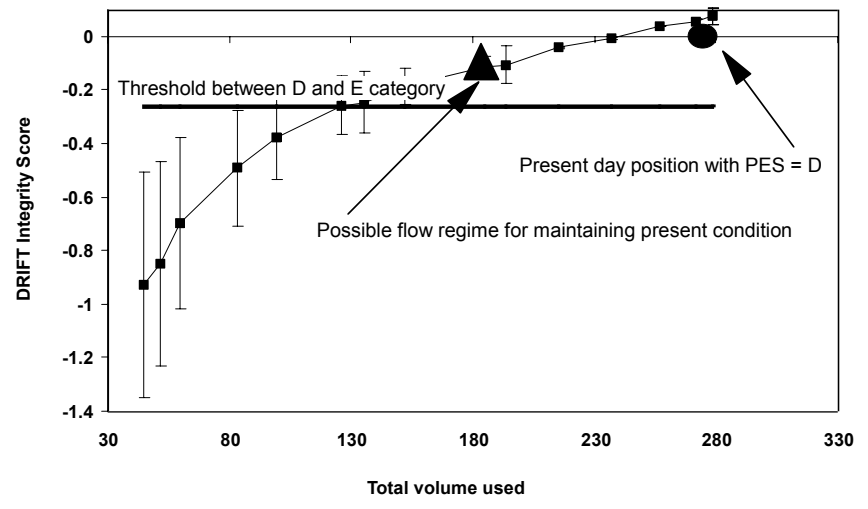

Figure 4

The DRIFT category output for EWR Site 1

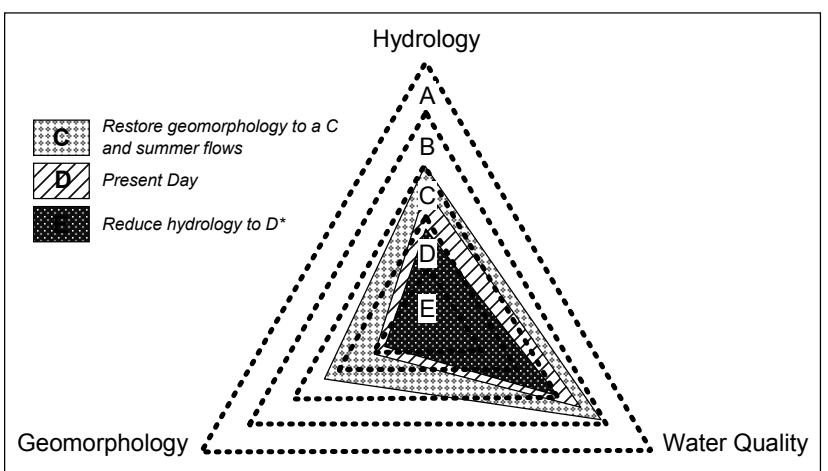

Figure 5

Radar diagram indicating how changes to one of the drivers (hydrology, water quality and geomorphology) of ecosystem condition can affect the overall ecological category of the river. * would still require reinstatement of summer flows 


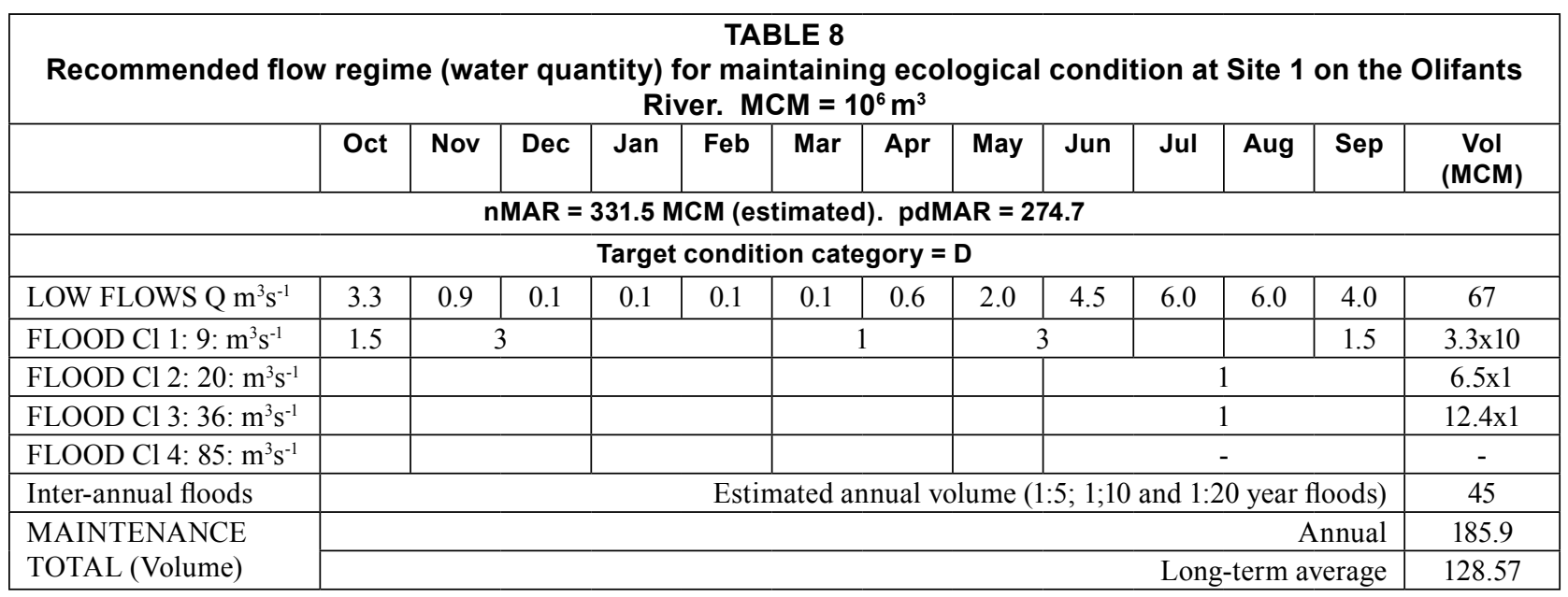

For scenarios that shift and ecosystem away from natural, the assumption behind this are (Brown and Joubert, 2003):

- If at least $85 \%$ of the individual Integrity Ratings are $\geq-1$, then the ecosystem will remain in the present category (e.g., Category D for Site 1 on the Olifants River)

- If at least $85 \%$ of the individual Integrity Ratings are $\geq-2$, then the ecosystem will shift to the next lowest category (e.g., Category D (present) to Category E (predicted) for Site 1 on the Olifants River).

The improvement in condition was not deemed to be sufficient to result in improvement to one category up, i.e., a C-category, and thus none is shown. The 'confidence limits' shown around each data point indicate the range of uncertainty expressed by the specialists when returning their predictions.

According to the National Water Act (NWA, 1998) and DWAF policy, the Ecological Reserve should strive to maintain river systems in their current condition (or improve the condition if it is a category lower than D). Thus a first step in determining the Reserve for Site 1 would be to recommend a flow regime for maintaining the present condition, which in Fig. 4 could be selected at any point above the threshold between $\mathrm{D}$ and $\mathrm{E}$ category such as the point demarcated by the triangle.

\section{Flow regime for maintaining the present day ecological condition}

The annual summary for the flow regime (quantity only) recommended for maintaining present-day ecological condition is provided in Table 7. The annual volume requested for the environmental flow under the scenario shown in Table 7 is 185.9 $\mathrm{MCM} / \mathrm{a}$, i.e., $56 \%$ of nMAR, and $89 \mathrm{MCM} / \mathrm{a}$ less than presentday flow at the site. It should be noted that values given are an ESTIMATE of the flows required and that actual volumes depend on the climate. The following mix of change levels for the 10 components was selected:

1 Wet season low flows

2 Dry season low flows:

3 Class 1 Intra-annual floods:

4 Class 2 Intra-annual floods:
5 Class 3 Intra-annual floods:

6 Class 4 Intra-annual floods:

7 Inter-annual floods (1:2 year):

8 Inter-annual floods (1:5 year):

9 Inter-annual floods (1:10 year): Present day

10 Inter-annual floods (1:20 year): Present day.

DRIFT SOLVER actually selected Change Level 3 for the dry season low flows, i.e., reinstate the dry season low flows to the 50th percentile of natural (see Table 2), thus highlighting the perceived importance of dry season low flows. However, the practicalities of reinstating the required flows are such that DRIFT's output was adjusted to Level 2 change dry season low flow, viz. 0.001 minimum flows during the dry season, and Level 3 change wet season low flow. This results in a slightly higher DRIFT integrity score but was deemed to be a more realistic option. Flow cessation during the dry season (as occurs presently) is extremely damaging to the river as riffles, runs and (often) pools dry up, leaving no riverine habitat, and thus should not form part of any recommended flow regime for the river.

Some of the ten Class 1 floods recommended were required in the wet season, which makes up for some of the variability lost by reducing the wet season low flows.

The annual volume given in Table 8 is calculated as the volume of water required to meet the full requirements every year. However, this is often not the case as requested flows will only be provided if climatic events occur that would naturally have stimulated them, e.g., if there is no rainfall event in October, then the Class 1 flood requested for that month would not be 'supplied'. This means that the actual volume of water 'used' by the river would usually be less than that requested in Table 8 , as illustrated by the long-term average, which is calculated using the historical flow sequence, and only 'releasing' requirements in response to 'natural' cues. Additional detail on the requested flood requirements is given in Table 9. Similar breakdowns can be supplied for each of the data points in Fig. 5.

For a Reserve determination the information provided in Table 8 is typically augmented with so-called 'rule or exceedance data' (Tables 9 and 10), which facilitate operationalisation of the Reserve and, in particular, incorporation of the Reserve requirements into the appropriate water resources model so that the practicalities and/or impacts of providing such in a stressed catchment can be evaluated. 


\begin{tabular}{|c|c|c|c|c|c|c|c|c|c|c|c|c|c|c|}
\hline & & Excee & lance & lata for & he co & iplete & ow res & me sh & vn in & ble 4 & MCM & $0^{6} \mathrm{~m}^{3}$ & & \\
\hline Month & & & & & & centil & (data a & $e$ in $m^{3} s$ & & & & & & \\
\hline & 1 & 5 & 10 & 20 & 30 & 40 & 50 & 60 & 70 & 80 & 90 & 95 & 99 & \\
\hline All & 69.087 & 9.726 & 6.012 & 4.354 & 3.408 & 2.241 & 1.752 & 0.905 & 0.274 & 0.01 & 0.01 & 0.01 & 0.01 & 128.567 \\
\hline Jan & 3.41 & 1.219 & 0.773 & 0.323 & 0.05 & 0.01 & 0.01 & 0.01 & 0.01 & 0.01 & 0.01 & 0.01 & 0.01 & 0.661 \\
\hline Feb & 0.69 & 0.47 & 0.27 & 0.01 & 0.01 & 0.01 & 0.01 & 0.01 & 0.01 & 0.01 & 0.01 & 0.01 & 0.01 & 0.16 \\
\hline Mar & 2.238 & 1.57 & 0.8 & 0.428 & 0.01 & 0.01 & 0.01 & 0.01 & 0.01 & 0.01 & 0.01 & 0.01 & 0.01 & 0.637 \\
\hline Apr & 4.06 & 3.532 & 2.525 & 1.795 & 1.257 & 0.891 & 0.607 & 0.363 & 0.152 & 0.01 & 0.01 & 0.01 & 0.01 & 2.683 \\
\hline May & 9.705 & 2.383 & 2.088 & 2.03 & 2.022 & 2.013 & 2.008 & 2 & 1.8 & 1.508 & 0.955 & 0.522 & 0.009 & 5.281 \\
\hline Jun & 120.9 & 43.147 & 10.913 & 4.548 & 4.526 & 4.515 & 4.508 & 4.501 & 4.072 & 3.288 & 2.181 & 1.927 & 1.31 & 25.092 \\
\hline Jul & 154.42 & 70.38 & 38.196 & 15.127 & 6.137 & 6.049 & 6.013 & 6.004 & 5.698 & 4.19 & 3.12 & 1.69 & 1.17 & 40.801 \\
\hline Aug & 84.456 & 38.822 & 19.608 & 6.088 & 6.042 & 6.026 & 6.003 & 6 & 5.686 & 4.193 & 2.912 & 2.365 & 1.496 & 25.741 \\
\hline Sep & 70.38 & 12.14 & 4.206 & 4.035 & 4.03 & 4.023 & 4.012 & 4 & 3.95 & 3.221 & 2.056 & 1.564 & 1.027 & 15.275 \\
\hline Oct & 4.499 & 3.665 & 3.398 & 3.337 & 3.307 & 3.3 & 3.27 & 2.578 & 1.98 & 1.465 & 0.96 & 0.39 & 0.1 & 7.068 \\
\hline Nov & 4.52 & 3.665 & 3.061 & 2.241 & 1.832 & 1.377 & 1.056 & 0.848 & 0.649 & 0.279 & 0.01 & 0.01 & 0.01 & 3.449 \\
\hline Dec & 4.289 & 2.425 & 1.832 & 0.975 & 0.584 & 0.359 & 0.105 & 0.01 & 0.01 & 0.01 & 0.01 & 0.01 & 0.01 & 1.719 \\
\hline
\end{tabular}

\section{TABLE 10}

Exceedance data for the low-flow component of the flow regime shown in Table 4. $M C M=10^{6} \mathrm{~m}^{3}$

\begin{tabular}{|c|c|c|c|c|c|c|c|c|c|c|c|c|c|c|}
\hline \multirow[t]{2}{*}{ Month } & \multicolumn{13}{|c|}{ Percentiles (data are in $\mathrm{m}^{3} \cdot \mathrm{s}^{-1}$ ) } & \multirow{2}{*}{$\begin{array}{c}\text { MAR } \\
\text { [MCM] }\end{array}$} \\
\hline & 1 & 5 & 10 & 20 & 30 & 40 & 50 & 60 & 70 & 80 & 90 & 95 & 99 & \\
\hline Jan & 3.411 & 3.291 & 1.901 & 0.747 & 0.144 & 0.01 & 0.01 & 0.01 & 0.01 & 0.01 & 0.01 & 0.01 & 0.01 & 14.902 \\
\hline Feb & 3.41 & 1.18 & 0.76 & 0.31 & 0.05 & 0.01 & 0.01 & 0.01 & 0.01 & 0.01 & 0.01 & 0.01 & 0.01 & 0.625 \\
\hline Mar & 0.69 & 0.47 & 0.27 & 0.01 & 0.01 & 0.01 & 0.01 & 0.01 & 0.01 & 0.01 & 0.01 & 0.01 & 0.01 & 0.16 \\
\hline Apr & 2.01 & 1.57 & 0.74 & 0.39 & 0.01 & 0.01 & 0.01 & 0.01 & 0.01 & 0.01 & 0.01 & 0.01 & 0.01 & 0.611 \\
\hline May & 2.134 & 2.084 & 2.053 & 2.027 & 2.016 & 2.012 & 2.006 & 2 & 1.7 & 1.38 & 0.85 & 0.37 & 0 & 4.562 \\
\hline Jun & 4.716 & 4.638 & 4.55 & 4.528 & 4.518 & 4.513 & 4.506 & 4.5 & 4.01 & 3.22 & 2.18 & 1.87 & 1.31 & 10.285 \\
\hline \begin{tabular}{|l|} 
Jul \\
\end{tabular} & 6.32 & 6.214 & 6.096 & 6.049 & 6.024 & 6.011 & 6.007 & 6 & 5.62 & 4.19 & 3.12 & 1.69 & 1.17 & 14.165 \\
\hline Aug & 6.095 & 6.087 & 6.066 & 6.038 & 6.021 & 6.003 & 6 & 6 & 5.16 & 3.94 & 2.82 & 2.23 & 1.39 & 13.891 \\
\hline Sep & 4.625 & 4.056 & 4.041 & 4.032 & 4.027 & 4.02 & 4.01 & 4 & 3.93 & 3.15 & 2.03 & 1.48 & 0.96 & 9.315 \\
\hline Oct & 3.411 & 3.401 & 3.371 & 3.33 & 3.304 & 3.3 & 3.26 & 2.47 & 1.97 & 1.39 & 0.85 & 0.39 & 0.1 & 6.699 \\
\hline Nov & 4.52 & 3.47 & 2.67 & 2.07 & 1.54 & 1.28 & 0.99 & 0.8 & 0.59 & 0.18 & 0.01 & 0.01 & 0.01 & 3.213 \\
\hline Dec & 2.72 & 2.05 & 1.43 & 0.78 & 0.51 & 0.33 & 0.08 & 0.01 & 0.01 & 0.01 & 0.01 & 0.01 & 0.01 & 1.208 \\
\hline
\end{tabular}

\section{Discussion}

In today's world, where competition for resources, in particular water, is high, it is essential that methods and tools used to manage river ecosystems are able to maximise the use of information available to them. They also need to be able to provide quick and simple, but meaningful, inputs to decisions involving tradeoffs between different uses of water and the implications for sustainable development of water resources.

Once populated with predictions from the specialists, the DRIFT database can be used to explore numerous management-related questions in addition to providing a range of scenarios linking flow and river condition. The results presented here from Site 1 indicate there is some opportunity for further abstractions from the river while still maintaining a D-category river BUT only if some summer flows are reinstated. However, an examination of the ecoclassification assessments and the DRIFT category plot show that additional water could be made available at Site 1, provided restoration work was undertaken to address some of the non-flow related impacts on the river.

Ecoclassification involves the combination of several aspects of the river, e.g., hydrological, geomorphological, chemical and biological aspects, to arrive at a weighed average (e.g. Kleyn- hans et al., 2005). This means that if one aspect is in poorer condition than the others, the overall condition score for the system will be reduced. Conversely, an aspect in good condition will help in supporting a higher score. At Site 1, although the overall condition of the river is a D-category, one of the 'drivers' of river condition, geomorphology, is in an E (Fig. 5) as a result of nonflow related impacts on the river system, such as bulldozing of the channel, cultivation of the alluvial floodplains and encroachment of alien and other riparian vegetation. This has two major management implications:

- If the hydrological regime is further restricted (i.e., beyond that indicated by DRIFT category), without undertaking any measures to restore other components of the system, this will result in the river falling to an E category (Fig. 5)

- If, however, river restoration work were undertaken to improve the condition of the geomorphology, this would improve the overall condition. This could mean that the present day starting point (DRIFT Integrity Score $=0$ ) could be at a Category C. This would mean one of two things: either the flow regime shown in Table 8 would support a $\mathrm{C}$-category river; or more water could be made available for abstraction, while still maintaining a D-category river as per the legal requirements. 


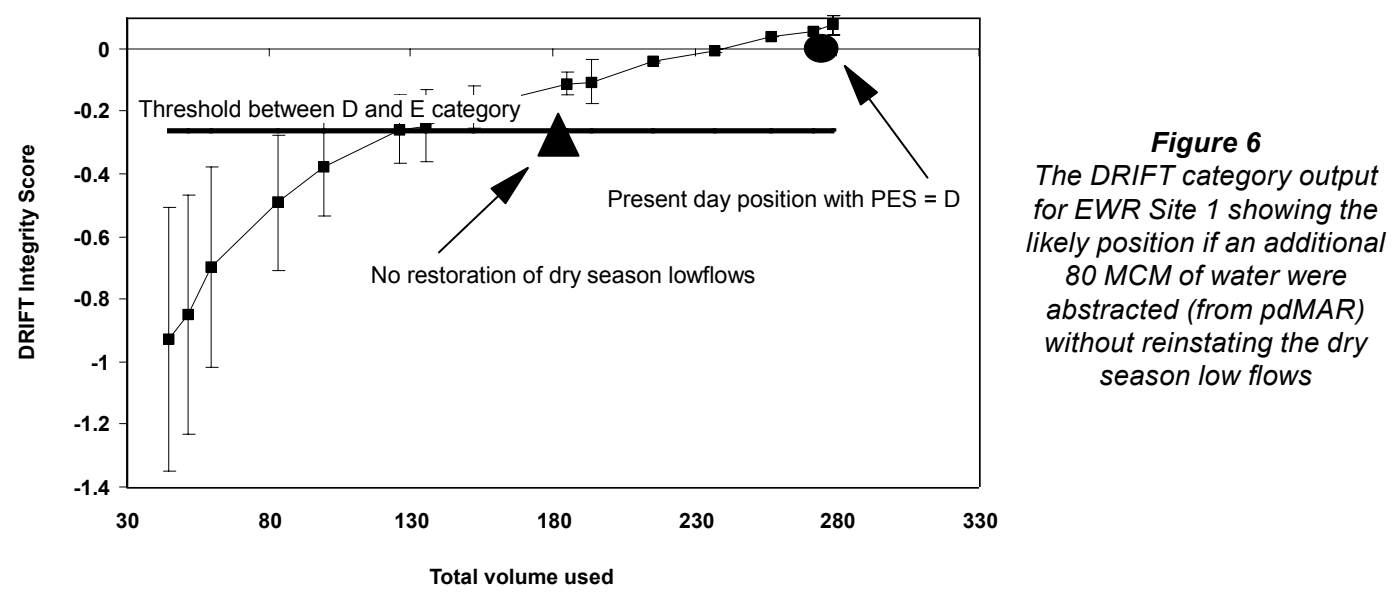

This means that the actions of the land-owners adjacent to the river reach represented by Site 1 may themselves be restricting the amount of water they can legally abstract.

It is worth noting that, in comparison with other estimates for maintenance of a D-category river (Hughes and Münster, 2000; Brown and Louw, 2001; Brown et al., 2000), the 56\% nMAR recommended here for Site 1 is considered high for the Western Cape, and could conceivably be reduced to $c .35 \%$ with the restoration of the other components so that they share the 'load' of supporting a D-category. Theoretically, this could make available an additional c. $70 \mathrm{MCM}$ of water per annum (on average), which in the context of the value of water in the Olifants River valley is a substantial amount of water.

The requirement for reinstating summer flows also carries with it serious management implications. In the Western Cape because the growing season (summer) is the dry time of the year, any water abstracted in the wet season would have to be stored in off-channel storage dams for later use. This of course could have considerable financial implications for farmers in the area, and will need to be strongly motivated for if it is to receive the support of DWAF and water user associations (WUAs) in the area. Thus, using DRIFT category, we can also explore the implications for river condition of additional water abstraction without taking cognizance of the distribution of water. For instance, Fig. 6 shows the resultant position in terms of the river should $80 \mathrm{MCM}$ of additional water be taken from the system without restoring any of the dry season low flows.

Basically, the results suggests that without restoring the dry season flows the river is likely to move from a D to an Ecategory, which would not meet the government-recommended minimum requirement for a D-category or higher (DWAF, 1999; 2002). Thus, if the NWA is to be implemented, the costs of wet season abstraction for dry season irrigation will need to be brought into business plans for farms in the area. In this instance though it is worth noting that the actual additional volume of water required in the dry season is very small (c. $0.01 \mathrm{MCM}$ per annum) but the ecological value of that water is extremely high (c. 4 DRIFT Integrity points per MCM). Interestingly, adding more water (i.e., Change Level 3), while deemed beneficial, does not have as high a value attached to it: - 0.76 Integrity points for a 6.8 MCM (i.e., c. 0.1 DRIFT Integrity points per MCM).

In conclusion, open and clear communication between the various parties is essential if feasible and equitable tradeoffs between water users are to be achieved. Such communication is enhanced and supported by effective and ideally objective information that will not only allow evaluation of a range of possibilities but also highlight opportunities for innovative and creative interventions, where appropriate. It is hoped that, regardless of the eventual outcome of water user negotiations on the middle Olifants River, the sort of information presented here will contribute towards a more directed and open discussion on the current opportunities and constraints with respect to water availability in that part of the world.

\section{Acknowledgements}

We thank the South African Department of Water Affairs and Forestry for funding this work, in particular the Resource Directed Measures (RDM) Directorate and the Department's Regional Office (Western Cape) for their support of our methods and comments received. We thank Ninham Shand for their assistance during the study, and GEOSS for the GIS graphics. Thank you also to the landowners, who provided access to their farms and generally made us feel welcome. We gratefully acknowledge the financial support we have received from the Water Research Commission (WRC) over the years to develop aspects of DRIFT. Finally, thanks to the rest of the Southern Waters Ecological Research and Consulting team, Ros Townsend, Liz Frazer, Rodney February and Rembu Magoba, for their support and hard work over the two-year study.

\section{References}

ARTHINGTON AH, RALL JL, KENNARD MJ and PUSEY BJ (2003) Environmental flow requirements of fish in Lesotho rivers using the DRIFT methodology. Rivers Res. Appl. 19 (5-6) 641-666.

BIRKHEAD A, BOUCHER C, BROWN C, DOLLAR E, HARDING W, KAMISH W, PAXTON B, PEMBERTON C and RACTLIFFE S (2005) Olifants Doring Catchment Ecological Water Requirements Study. Riverine RDM Report. Vol. 1: Specialist Reference Report. Southern Waters' Consultancy Report to DWAF: RDM Directorate. Project No. 2002-376. 309 pp.

BROWN CA, PEMBERTON C, GREYLING A and KING JM (2005) DRIFT User Manual. Vol. 1: Biophysical Module for Predicting Overall River Condition in Small to Medium Sized Rivers with Relatively Predictable Flow Regimes. WRC Report No. 1404/1/05. Water Research Commission, Pretoria. $100 \mathrm{pp}$.

BROWN CA, DOLLAR E, HARDING WR, PEMBERTON C, TALJAARD S and VAN NIEKERK L (2004) Olifants Doring Catchment Ecological Water Requirements Study. Delineation Report. Southern Waters' Consultancy Report to DWAF: RDM Directorate. $83 \mathrm{pp}$.

BROWN CA and LOUW D (2002) Breede River Basin: DRIFT Application. DRIFT: WRC Report Set No. 177005 3581. Report to Water Research Commission and Department of Water Affairs and Forestry, South Africa. Unpublished Consultancy Report. 
BROWN CA and JOUBERT A (2003) Using multicriteria analysis to develop environmental flow scenarios for rivers targeted for water resource development. Water SA 29 (4) 365-374.

BROWN CA, PEMBERTON C, TALJAARD S and VAN NIEKERK L (2003) Olifants Doring Catchment Ecological Water Requirements Study. Inception Report. Southern Waters' Consultancy Report to DWAF: RDM Directorate. Project No. 2002-376. 138 pp.

BROWN CA and PEMBERTON C (2005) Olifants Doring Catchment Ecological Water Requirements Study. Riverine RDM Report. Volume 2: Environmental Water Requirements. Southern Waters' Consultancy Report to DWAF: RDM Directorate. Project No. 2002-376. $85 \mathrm{pp}$.

BROWN CA, SPARKS A and HOWARD G (2000) Palmiet River instream flow assessment: instream flow requirement for the riverine ecosystem. Proc. IFR Workshop and Determination of Associated Dam Yields. In: Southern Waters' Consultancy Report No. G400-00-0499 to the South African Department of Water Affairs and Forestry. $168 \mathrm{pp}$.

DALLAS HF (1997) Impacts of the Water Resource Developments on the Riverine Ecosystem. Vol. 2: Olifants River Situation Assessment. Southern Waters' Consultancy Report to the Department of Water Affairs and Forestry. $52 \mathrm{pp}$.

DEPARTMENT OF WATER AFFAIRS AND FORESTRY (1999) Resource Directed Measures for Protection of Water Resources. Vol. 3: River Ecosystems Version 1. September 1999. Pretoria. Report No N/29/99.

DEPARTMENT OF WATER AFFAIRS AND FORESTRY (2002) National Water Resource Strategy: Summary. Government Printers. Pretoria.
GORDON ND, McMAHON TA and FINLAYSON BL (1992) Stream Hydrology. An Introduction for Ecologists. John Wiley and Sons, Queensland, Australia.

HUGHES DA and MÜNSTER F (2000) Hydrological Information and Techniques to Support the Determination of the Water Quantity Component of the Ecological Reserve for Rivers. WRC Report No. $867 / 3 / 2000$. Report to the Water Research Commission, Pretoria by the Institute for Water Research, Rhodes University, South Africa.

JOOSTE S (2004) Personal communication. Water Resource Quality Institute. Department of Water Affairs and Forestry, Pretoria.

KING JM, BROWN CA and SABET H (2003) A scenario-based holistic approach to environmental flow assessments for regulated rivers. Rivers Res. Applic. 19 (5-6) 619-640.

KLEYNHANS CJ (1996) A qualitative procedure for the assessment of the habitat integrity status of the Luvuvhu River (Limpopo system, South Africa). J. Aquat. Ecosyst. Health 5 41-54.

KLEYNHANS CJ, LOUW MD, THIRION C, ROSSOUW $\mathrm{N}$ and ROWNTREE K (2005) River Classification: Manual for Ecostatus Determination. First Draft for Training Purposes. DWAF, Pretoria.

LOUW MD and BIRKHEAD AL (1998) Crocodile River Preliminary Reserve: Site Selection Process. Department of Water Affairs and Forestry, Pretoria.

NATIONAL WATER ACT (1998) Act No. 36 of 1998. Government Gazette. Pretoria, South Africa.

VANNOTE RL, MINSHALL GW, CUMMINS GW, SEDELL JR and CUSHING CE (1980) The river continuum concept. Can. J. Fish. Aquat. Sci. 37 130-137. 
Available on website http://www.wrc.org.za ISSN 0378-4738 = Water SA Vol. 32 No. 2 April 2006 ISSN 1816-7950 = Water SA (on-line) 